\title{
PENGARUH KEPERCAYAAN DIRI DAN REWARD TERHADAP KEJENUHAN KERJA GURU HONOR SD NEGERI SE-KECAMATAN TUALANG KABUPATEN SIAK
}

\author{
Yulmaidar 1) \\ Makhdalena ${ }^{2)}$ \\ Wusono Indarto ${ }^{3}$ ) \\ 1) Post Graduate Student of Riau University \\ 2) Lecturer of Education Management Study Programme PPs University of Riau \\ ${ }^{3)}$ Lecturer of Education Management Study Programme PPs University of Riau
}

\begin{abstract}
This study aims to determine the effect of self-confidence and rewards to job burnout Elementary School teacher salaries sub-district of Tualang district of Siak, either simultaneously or partially. The population is 196 people, while the study sample as many as 131 people. The data analysis used is regression analysis, Results showed that there are significant negative silmultan confidence $\left(X_{1}\right)$ and reward $\left(X_{2}\right)$ on job burnout $(Y)$ amounted to $72.7 \%$ of teachers. While partially confidence $\left(X_{1}\right)$ negative effect on job burnout $(Y)$ amounted to $48.5 \%$ of teachers, and reward $(X 2)$ negative effect on job burnout of teachers by $4.5 \%$.
\end{abstract}

Keywords: Self-Confidence, Rewards, Job Burnout

\section{PENGARUH KEPERCAYAAN DIRI DAN REWARD TERHADAP KEJENUHAN KERJA GURU HONOR SD NEGERI SE-KECAMATAN TUALANG KABUPATEN SIAK}

\begin{abstract}
ABSTRAK
Penelitian ini bertujuan untuk mengetahui pengaruh kepercayaan diri dan reward terhadap kejenuhan kerja guru honor SD Negeri Se-Kecamatan Tualang Kabupaten Siak, baik secara simultan maupun parsial. Populasi dalam penelitian ini adalah 196 orang, sedangkan sampel penelitian sebanyak 131 orang. Analisis data yang digunakan yaitu analisis regresi berganda, Hasil penelitian menunjukkan bahwa secara silmultan terdapat pengaruh negatif kepercayaan diri $\left(\mathrm{X}_{1}\right)$ dan reward $\left(\mathrm{X}_{2}\right)$ terhadap kejenuhan kerja (Y) guru sebesar $72,7 \%$. Sedangkan secara parsial kepercayaan diri $\left(\mathrm{X}_{1}\right)$ berpengaruh negatif terhadap kejenuhan kerja (Y) guru sebesar 48,5\%, dan reward $\left(\mathrm{X}_{2}\right)$ berpengaruh negatif terhadap kejenuhan kerja guru sebesar $4,5 \%$.
\end{abstract}

Kata Kunci: Kepercayaan Diri; Reward; Kejenuhan Kerja 


\section{PENDAHULUAN}

Guru yang tergolong profesi dalam bidang pelayanan masyarakat, dalam bertugas memiliki beban kerja yang tidak sedikit. Dengan beban dan tuntutan kerja yang tinggi akan berdampak negatif pada performa kerja seseorang. Guru akan merasa tertekan dapat memunculkan sikap negatif pada siswa. Kondisi seperti inilah yang akhirnya dapat menjadi pemicu munculnya stres pada guru, yang apabila tidak dapat segera diatasi dengan baik, maka akan menyebabkan timbulnya stres yang berlebihan, dimana harapan yang tidak sesuai dengan kenyataan membuat guru menjadi lelah dan letih secara fisik dan psikologis, sehingga dapat mengganggu performa kerjanya, hal inilah yang disebut gejala kejenuhan kerja..

Sebuah sumber yang diungkapkan oleh Kleiber dan Enzman yang dikutip oleh Dhian dan Astuti (2010) menyatakan bahwa dari 2946 publikasi mengenai kejenuhan kerja, $43 \%$ terjadi pada bidang kesehatan dan pekerja sosial, $32 \%$ terjadi pada pengajar, 9\% terjadi pada adminitrasi dan manajemen, $4 \%$ pada pengacara dan polisi dan $12 \%$ terjadi pada kelompok lain seperti siswa, pasangan yang telah menikah dan pemeluk agama.

Dari hasil observasi sementara di salah satu Sekolah Dasar Negeri di Kecamatan Tualang, gejala kejenuhan kerja yang tampak pada sebagian guru honor yaitu kecemasan berlebihan, guru merasa tegang dalam melaksanakan proses belajar mengajar, mudah tersinggung dan munculnya gangguan fisik yaitu sakit kepala akibat murid yang susah diatur.

Sejalan dengan fenomena di atas, Pines dan Aronson yang dikutip oleh Diaz (2007) mendefinisikan kejenuhan kerja sebagai kelelahan secara fisik, emosional dan mental yang disebabkan keterlibatan jangka panjang dalam situasi yang penuh tuntutan emosional. Gambaran dari ke tiga dimensi tersebut adalah:

a. Kelelahan fisik, yaitu suatu kelelahan yang bersifat sakit fisik dan energi fisik. Sakit fisik dicirikan seperti sakit kepala, demam, sakit punggung, rasa ngilu, rentan terhadap penyakit, tegang pada otot leher dan bahu, sering terkena flu, susah tidur, mual-mual, gelisah, dan perubahan kebiasaan makan. Energi fisik dicirikan seperti energi yang rendah, rasa letih yang kronis, dan lemah.

b. Kelelahan emosional, yaitu suatu kelelahan pada individu yang berhubungan dengan perasaan pribadi yang ditandai dengan rasa tidak berdaya dan depresi. Kelelahan emosi ini dicirikan antara lain rasa bosan, mudah tersinggung, sinisme, perasaan tidak menolong, ratapan yang tiada henti, tidak dapat dikontrol, suka marah, gelisah, tidak peduli terhadap tujuan, tidak peduli dengan peserta didik orang lain, merasa tidak memilki apa-apa untuk diberikan, sia-sia, putus asa, sedih, tertekan, dan tidak berdaya.

c. Kelelahan mental, yaitu suatu kondisi kelelahan pada individu yang berhubungan dengan rendahnya penghargaan diri dan depersonalisasi. Kelelahan mental ini dicirikan antara lain merasa tidak berharga, rasa benci, rasa gagal, tidak peka, sinis, kurang bersimpati dengan orang lain, mempunyai sikap negatif terhadap orang lain, cenderung masa bodoh dengan dirinya, pekerjaannya dan kehidupannya, acuh tak acuh, pilih kasih, selalu menyalahkan, kurang bertoleransi terhadap orang yang ditolong, ketidakpuasan terhadap 
pekerjaan, konsep diri yang rendah, merasa tidak cakap, merasa tidak kompeten, dan tidak puas dengan jalan hidup

Fenomena lain yang terjadi di Sekolah Dasar Negeri yang berbeda terdapat sebagian guru honor yang mengalami gejala kejenuhan kerja seperti ketika pertama kali mengajar di sekolah tersebut dengan pendapatan yang kurang memuaskan (honor BOS), guru tersebut memiliki kedisiplinan yang tinggi, setelah pendapatan meningkat (honor daerah) produktifitas kerja guru tersebut menjadi menurun, muncul perasaan tidak efektif dan kurang kompeten dalam menjalankan tugas sebagai guru serta terlihat lelah setelah melaksanakan aktiftas belajar mengajar.

Dalam kaitannya dengan fenomena-fenomena tersebut, Sujipto dalam Maharani (2011) menilai bahwa pendidikan dasar sangat ditentukan oleh kualitas guru. Guru Sekolah Dasar mempunyai peranan yang utama dalam mengarahkan anak didiknya untuk mewujudkan tujuan pendidikan. Hal ini tidak lepas bahwa anak sekolah dasar adalah peletak dasar bagi terciptanya sumber daya manusia yang berkualitas. Berdasarkan uraian di atas, variabel yang diduga berpengaruh terhadap kejenuhan kerja yaitu beban kerja, kepercayaan diri, locus of control, rutinitas yang monoton, dukungan sosial dan reward. Sedangkan variabel yang diduga kuat berpengaruh dengan kejenuhan kerja yaitu kepercayaan diri dan reward.

Selanjutnya, Shinn $d k k$ dalam Rahman (2007) mengemukakan bahwa kejenuhan kerja merupakan tekanan psikis yang dirasakan oleh seseorang yang bekerja di lingkungan yang melibatkan banyak orang. Apalagi jika pekerjaan tersebut dilakukan oleh orang yang memiliki komitmen berlebihan dan melibatkan dari dalam pekerjaan, tentu akan merasa kecewa jika tidak berimbang antara usaha yang dilakukan dan imbalan yang diterima. Hal ini akan menimbullkan rasa gagal dan berdampak pada menurunnya penilaian terhadap kompetensi diri dan memicu munculnya rasa kurang percaya diri. Dari pendapat di atas, dapat dijelaskan bahwa kepercayaan diri merupakan sikap yang mengakui dan meyakini kemampuan yang dimiliki dalam mencapi target tertentu. Oleh sebab itu, kepercayaan diri wajib dimiliki oleh setiap orang agar terhindar dari dampak kejenuhan.

Yusuf (2005) menjelaskan bahwa kepercayaan diri artinya percaya pada diri sendiri, yakin akan kemampuan diri untuk menuju kreatifitas. Kepercayaan diri artinya membenarkan akal pikiran, percaya akan kemungkinan meningkatkan kemampuan intelektualitas dan percaya bahwa individu dapat mengukuhkan orientasi untuk memperoleh kemampuan akal lebih banyak lagi

Percaya diri merupakan kondisi mental atau psikologis seseorang yang memberi keyakinan kuat untuk berbuat atau bertindak. Di dalam panduan sistem penilaian, Direktorat PSMP (2014) terdapat beberapa indikator mengenai kepercayaan diri yaitu:

a. Berpendapat atau melakukan kegiatan tanpa ragu-ragu

b. Mampu membuat keputusan dengan cepat

c. Tidak mudah putus asa

d. Tidak canggung dalam bertindak

e. Berani presentasi di depan kelas

f. Berani berpendapat, bertanya atau mennjawab pertanyaan.

Disisi lain reward juga memiliki peranan penting dalam menurunkan dampak kejenuhan kerja guru. Wijanarko (2005) menjelaskan bahwa reward merupakan sesuatu yang 
diberikan kepada seseorang yang telah melakukan sesuatu yang dapat berupa pujian, perhatian, hadiah, barang, uang, janji dan lain-lain. Reward merupakan hal yang wajar sebagai apresiasi ucapan terimakasih kepada seseorang.

$$
\text { Schuler dan Huber dalam }
$$

Wanabakti dan Dwihardo (2011) menjelaskan bahwa reward adalah semua bentuk return baik finansial maupun nonfinansial yang diterima karyawan karena jasa yang disumbangkan ke perusahaan. Reward dapat berupa finansial yaitu berbentuk gaji, upah, bonus, komisi, asuransi karyawan, bantuan sosial karyawan, tunjangan libur atau cuti tetap dibayar dan sebagainya, maupun bentuk non finansial seperti tugas yang menarik, tantangan tugas, tanggung jawab tugas, peluang, pengakuan, pencapaian tujuan, serta lingkungan pekerjaan yang menarik.

Dalam kaitannya dengan kejenuhan kerja, Reyes $d k k$ (2008) menjelaskan bahwa pengakuan dan penghargaan yang cukup (baik keuangan, kelembagaan dan sosial) dapat meningkatkan kerentanan seseorang atau masyarakat terhadap dampak kejenuhan kerja. Sebab pekerjaan dan para kejerja sangat erat hubungannya dengan perasaan dalam diri.

Kejenuhan kerja adalah sindrom klinis yang ditandai dengan kelelahan fisik dan emosional, penilaian yang buruk, sinisme, rasa bersalah, perasaan ketidak-efektifan dan rasa depersonalisasi dalam hubungan dengan rekan kerja atau pasien (Cullen $d k k$ : 2013). Definisi di atas menjelaskan bahwa kejenuhan kerja merupakan suatu keadaan kelelahan baik secara fisik maupun psikis yang terjadi akibat adanya hubungan sosial antar sesama rekan kerja.

Sedangkan Olivia (2008) menjelaskan bahwa kejenuhan kerja dapat terjadi akibat kurangnya penghargaan positif dan dukungan sosial. Pekerja dituntut untuk tidak melakukan kekeliruan sedikit pun dan jarang mendapat pujian atau penghargaan atas kerja keras mereka selama menangani masalah. Namun jika di kantor ada kelompok-kelompok pendukung yang membuat untuk memberikan umpan balik serta pujian, ternyata kejenuhan kerja yang dilihat dari banyaknya pengunduran diri dan dari kepuasan karyawan akan jauh berkurang dan dapat meningkatkan kepercayaan diri pekerja.

Dari penjelaskan di atas dapat ditegaskan bahwa reward akan mempengaruhi kejenuhan kerja pada guru dalam melakukan tugasnya. Dengan demikian diduga terdapat engaruh reward terhadap kejenuhan kerja pada guru honor. Semakin tinggi reward yang diperoleh, maka kejenuhan kerja pada guru akan semakin rendah. Sebaliknya, semakin rendah reward yang diperoleh, maka kejenuhan kerja pada guru akan semakin tinggi. Oleh karena itu reward padat berfungsi memotivasi seseorang dalam meningkatkan produktifitas kerjanya agar terhindar dari dampak kejenuhan kerja. Berdasarkan uraian di atas, secara garis besar kerangka berfikir dalam penelitian ini dapat dilihat pada gambar 1 berikut ini: 


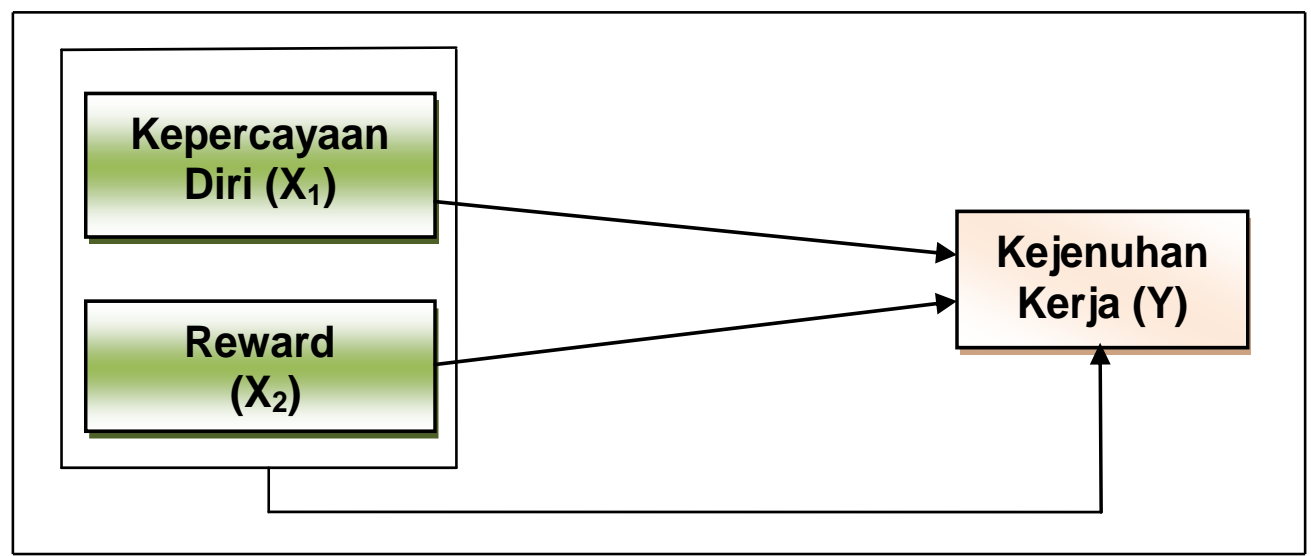

Gambar 1. Kerangka berfikir

Berdasarkan pada landasan teori dan kerangka pemikiran tersebut di atas, hipotesis yang diajukan dalam penelitian ini adalah kepercayaan diri dan reward berpengaruh terhadap kejenuhan kerja baik secara simultan dan parsial.

\section{METODOLOGI PENELITIAN}

Pendekatan penelitian ini merupakan penelitian pengembangan dengan metode survey deskriptif. Penelitian survey dimaksudkan untuk memperoleh gambaran umum mengenai kejenuhan kerja pada guru. Penelitian ini dilaksanakan di SD Negeri Se-Kecamatan Tualang Kabupaten Siak. Adapun waktu penelitian dilakukan selama 3 bulan yaitu pada bulan Juni sampai dengan bulan Agustus tahun 2015.

Dalam penelitian ini menggunakan jenis data primer dan data sekunder. Data primer berupa data mentah yang berasal dari responden terhadap pertanyaan-pertanyaan yang mengacu pada variabel kepercayaan diri dan reward yang sampai pada akhirnya apakah berhubungan dengan kejenuhan kerja. Data primer tersebut yang nantinya akan diolah. Sedangkan data sekunder antara lain kepustakaan serta bahan dari internet. Sumber data dalam penelitian ini adalah guru yang termasuk sebagai sampel penelitian.

Populasi dalam penelitian ini adalah seluruh guru honor SD Negeri Se-Kecamatan Tualang Kabupaten Siak berjumlah 196 orang. Pada penelitian ini untuk menarik ukuran sampel dari populasi digunakan rumus Yamane dalam Ridwan, yaitu:

$$
n=\frac{N}{N \cdot d^{2}+1}
$$

Keterangan:

$\mathrm{n}=$ ukuran sampel

$\mathrm{N}=$ Ukuran populasi

$\mathrm{d}=$ Presisi yang ditetapkan

Sehingga diperoleh besarnya sampel sebagai berikut:

$$
n=\frac{196}{196 \cdot(0,05)^{2}+1}=\frac{196}{1,49}=\approx 131
$$

Setelah ditentukan terdapat 131 responden yang akan dijadikan sampel. Untuk menentukan sampel disetiap sekolah yang akan kita teliti maka digunakan teknik proportional random sampling. Teknik ini menggunakan cara pengambilan sampel dari anggota populasi yang berada dalam kelompok berbeda dan jumlah proporsional dengan asumsi setiap kelompok 
mempunyai karakteristik yang homogen.

Pengumpulan data dalam penelitian ini menggunakan teknik angket (kuesioner), yang telah diuji validasi dan reliabilitinya. Pengukuran setiap jawaban responden pada penelitian ini menggunakan skala Likert yang biasa digunakan untuk mengukur sikap, pendapat, dan persepsi seseorang tentang fenomena sosial. Menurut Sugiyono, dengan skala Likert, maka variabel yang akan diukur dijabarkan menjadi indikator variabel. Kemudian indikator tersebut dijadikan sebagai titik tolak untuk menyusun item-item instrument yang dapat berupa pernyataan atau pertanyaan. Jawaban setiap item instrumen pada penelitian ini adalah dengan memilih salah satu dari lima pilihan yang tersedia, yaitu: (1) Sangat Tidak Setuju; (2) Tidak Setuju; (3) Kurang Setuju; (4) Setuju; dan (5) Sangat Setuju.

Dalam penelitian ini untuk melakukan pengujian hipotesis penelitian pengaruh kepercayaan diri dan reward terhadap kejenuhan kerja pada guru honor SD Negeri SeKecamatan Tualang Kabupaten Siak tahun 2015. Menggunakan regresi berganda dengan bantuan SPSS V. 17. Analisis regresi berganda dalam penelitian ini dapat dinyatakan dalam bentuk persamaan regresi berganda dengan rumus:

Regresi

$$
\begin{aligned}
& \qquad \hat{\mathbf{Y}}=\mathbf{a}+ \\
& \qquad \mathbf{b}_{1} \mathbf{X}_{1}+\mathbf{b}_{2} \mathbf{X}_{2} \\
& \text { Keterangan: } \\
& \hat{Y}=\text { Kejenuhan Kerja } \\
& \mathrm{a}=\text { Konstanta } \\
& \mathrm{b} \quad=\text { Pengaruh/Koefisian }
\end{aligned}
$$

$$
\begin{aligned}
\mathrm{X}_{1} & =\text { Kepercayaan diri } \\
\mathrm{X}_{2} & =\text { Reward }
\end{aligned}
$$

Berikut ini akan dijelaskan definisi konseptual, definisi operasional sebagai berikut:

1. Variabel Kejenuhan Kerja

Definisi konseptual variabel kejenuhan kerja merupakan keadaan stres yang dialami individu dalam jangka waktu yang lama dan dengan intensitas yang cukup tinggi akibat tidak seimbangnya antara tuntutan dan harapan yang dapat diukur dengan indikator kelelahan fisik, mental dan emosional.

Secara operasional kejenuhan kerja merupakan keadaan stres yang dialami individu dalam jangka waktu yang lama dan dengan intensitas yang cukup tinggi akibat tidak seimbangnya antara tuntutan dan harapan yang dapat diukur dari skor total jawaban guru honor SD Negeri Se-Kecamatan Tualang Kabupaten Siak dengan indikator kelelahan fisik, mental dan emosional.

\section{Variabel Kepercayaan Diri}

Secara konseptual kepercayaan diri adalah kondisi mental atau psikologis seseorang, dimana individu dapat mengevaluasi keseluruhan dari dirinya sehingga memberi keyakinan kuat pada kemampuan dirinya untuk melakukan tindakan dalam mencapai berbagai tujuan di dalam hidupnya yang dapat diukur dengan indikator melakukan pekerjaan tanpa ragu-ragu, tidak canggung dalam bekerja dan tidak mudah putus asa dalam menjalankan tugas.

Secara operasional kepercayaan diri adalah kondisi mental atau psikologis seseorang, dimana individu dapat mengevaluasi keseluruhan dari dirinya sehingga memberi keyakinan kuat pada kemampuan dirinya untuk melakukan tindakan dalam mencapai berbagai tujuan di dalam hidupnya yang 
dapat diperoleh dari skor jawaban guru honor SD Negeri di Kecamatan Tualang Kabupaten Siak yang mengukur indikator melakukan pekerjaan tanpa ragu-ragu, tidak canggung dalam bekerja dan tidak mudah putus asa dalam menjalankan tugas.

3. Variabel Reward (Penghargaan)

Definisi konseptual reward adalah suatu bentuk penghargaan atau penguatan yang diberikan kepada seseorang yang bersifat menyenangkan perasaan sehingga menimbulkan keinginan dalam diri seseorang untuk melakukan hal yang baik dan lebih baik lagi pada masa yang akan datang yang dapat diukur dengan indikator reward material dan non material.

Secara operasional reward adalah suatu bentuk penghargaan atau penguatan yang diberikan kepada seseorang yang bersifat menyenangkan perasaan sehingga menimbulkan keinginan dalam diri seseorang untuk melakukan hal yang baik dan lebih baik lagi pada masa yang akan datang yang diperoleh dari skor jawaban guru honor SD Negeri Se-Kecamatan Tualang Kabupaten Siak yang dapat diukur dengan indikator reward material dan non material.

\section{HASIL PENELITIAN DAN PEMBAHASAN \\ 1. Deskriptif Data}

Berdasarkan hasil perhitungan terhadap data kejenuhan kerja diperoleh skor empiris terendah yang dicapai responden adalah 72 dan skor tertinggi adalah 110. Dengan demikian, rentang skor empiris adalah sebesar 38 . Perhitungan terhadap distribusi skor kejenuhan kerja menghasilkan: (1) skor mean $=95,21$, (2) skor median $=95,(3)$ skor modus $=93$ dan (4) skor simpangan baku $=8,241$.

Selanjutnya, derdasarkan hasil perhitungan terhadap data kepercayaan diri diperoleh skor empiris terendah yang dicapai responden adalah 78 dan skor tertinggi adalah 117. Dengan demikian, rentang skor empiris adalah sebesar 39. Perhitungan terhadap distribusi skor kepercayaan diri menghasilkan: (1) skor mean $=95,85$ (2) skor median $=94$, (3) skor modus $=$ 92, dan (4) skor simpangan baku = 9,268 .

Sedangkan berdasarkan hasil perhitungan terhadap data reward diperoleh skor empiris terendah yang dicapai responden adalah 79 dan skor tertinggi adalah 117. Dengan demikian, rentang skor empiris adalah sebesar 38 . Perhitungan terhadap distribusi skor reward menghasilkan: (1) skor mean = 101,03 (2) skor median = 101 (3) skor modus $=99$, dan (4) skor simpangan baku $=6.466$.

\section{Uji Normalitas}

Uji normalitas data pada penelitian ini menggunakan uji Kolmogorov_smirnov, dengan taraf signifikan yang digunakan sebagai aturan untuk menerima atau menolak pengujian normalitas atau ada tidaknya suatu distribusi data $\alpha=0,05$. Untuk menerima atau menolak hipotesis dengan cara membandingkan nilai signifikan variabel dengan $\alpha=0,05$. Adapun kaidah keputusan, data dinyatakan berdistribusi normal jika nilai signifikan $>\alpha=0,05$.

\section{Uji Homogenitas}

Dari hasil perhitungan yang telah dilakukan bahwa nilai signifikan variabel kejenuhan kerja (Y) berdasarkan variabel kepercayaan diri $\left(\mathrm{X}_{1}\right)$ yaitu $0,104>0,05$. Artinya data variabel kejenuhan kerja (Y) berdasarkan variabel kepercayaan diri $\left(\mathrm{X}_{1}\right)$ mempunyai varian yang sama atau homogen. Sedangkan nilai signifikan variabel kejenuhan kerja 
berdasarkan variabel reward $\left(\mathrm{X}_{2}\right)$ yaitu $0,135>0,05$. Artinya data variabel kejenuhan kerja (Y) berdasarkan variabel reward $\left(\mathrm{X}_{2}\right)$ mempunyai varian yang sama atau homogen.

\section{Uji Multikolinearitas}

Hasil pengujian multikolinearitas menunjukan bahwa kepercayaan diri $\left(\mathrm{X}_{1}\right)$ dan reward $\left(\mathrm{X}_{2}\right)$ masing-masing mempunyai nilai toleransi sebesar 0,552 sedangkan nilai VIF masing-masing sebesar 1,812, maka tidak terdapat gangguan multikolinearitas pada penelitian ini. Sehingga penelitian ini bebas dan layak digunakan. Karena nilai toleransi di bawah 1, dan VIF di atas 1 maka dapat disimpulkan asumsi multikolinearitas terpenuhi yang berarti tidak terdapat hubungan diantara variabel bebas.

\section{Uji Hipotesis Penelitian}

a) Pengaruh Kepercayaan Diri $\left(\mathrm{X}_{1}\right)$ dan Reward $\left(\mathbf{X}_{2}\right)$ terhadap Kejenuhan Kerja (Y)

Hipotesis pertama yang diajukan dalam penelitian ini adalah "Terdapat pengaruh kepercayaan diri $\left(\mathrm{X}_{1}\right)$ dan reward $\left(\mathrm{X}_{2}\right)$ secara bersama-sama terhadap kejenuhan kerja (Y)". Sedangkan teknik analisis data yang digunakan dalam penelitian ini adalah regresi berganda.

Tabel 1. Pengujian Kekuatan Pengaruh Kepercayaan Diri dan Reward terhadap Kejenuhan Kerja

Model Summary

\begin{tabular}{|l|r|r|r|r|}
\hline Model & R & R Square & $\begin{array}{c}\text { Adjusted R } \\
\text { Square }\end{array}$ & $\begin{array}{c}\text { Std. Error of the } \\
\text { Estimate }\end{array}$ \\
\hline 1 & $.853^{\mathrm{a}}$ & .727 & .723 & 4.337 \\
\hline
\end{tabular}

a. Predictors: (Constant), Reward, Kepercayaan_Diri

Berdasarkan tabel 1, dapat ditunjukkan dari hasil perhitungan regresi $R$ Square yakni sebesar 0,727 . Hal ini menunjukkan bahwa ke dua variabel independen secara bersamasama mampu memberikan sumbangan terhadap variabel dependent sebesar
$72,7 \%$. Semakin tinggi kepercayaan diri dan reward yang di dapatkan maka semakin rendah kejenuhan kerjanya.

Selanjunya, berkenaan dengan persamaan regresi ganda dapat dilihat pada tabel 2.

Tabel 2. Koefisien Regresi Linear Kepercayaan Diri dan Reward terhadap Kejenuhan Kerja

Coefficients $^{\mathrm{a}}$

\begin{tabular}{|c|c|c|c|c|c|}
\hline \multirow[b]{2}{*}{ Model } & \multicolumn{2}{|c|}{$\begin{array}{c}\text { Unstandardized } \\
\text { Coefficients }\end{array}$} & \multirow{2}{*}{$\begin{array}{c}\text { Standardized } \\
\text { Coefficients }\end{array}$} & \multirow[b]{2}{*}{$\mathrm{T}$} & \multirow[b]{2}{*}{ Sig. } \\
\hline & $\mathrm{B}$ & Std. Error & & & \\
\hline 1 (Constant) & 8.639 & 5.955 & & 1.451 & .149 \\
\hline Kepercayaan_Diri & -.620 & .055 & .697 & 11.219 & .000 \\
\hline Reward & -.269 & .079 & .211 & 3.396 & .001 \\
\hline
\end{tabular}

a. Dependent Variable: Kejenuhan_Kerja 
Dari tabel 2, dapat dijelaskan bahwa kepercayaan diri $\left(\mathrm{X}_{1}\right)$ dan reward $\left(\mathrm{X}_{2}\right)$ secara bersama-sama terhadap kejenuhan kerja (Y) yang dapat disusun regresi yaitu $\hat{\mathbf{Y}}=\mathbf{8 , 6 3 9}-\mathbf{0 , 6 2 0} \mathrm{X}_{\mathbf{1}}$ $0,269 X_{2}$.

Tabel 3. Koefisien Korelasi Ganda Pengaruh Kepercayaan Diri dan Reward terhadap Kejenuhan Kerja

\begin{tabular}{|c|c|c|}
\hline No & Perhitungan & Hasil \\
\hline 1 & Korelasi $(\mathrm{r})$ & 0,853 \\
\hline 2 & Determinasi $\left(\mathrm{r}^{2}\right)$ & 0,727 \\
\hline
\end{tabular}

Dari tabel 3, koefisien determinasi $0,853^{2}=0,727$ atau $72,7 \%$. Ini berarti bahwa $72,7 \%$ variasi variabel kejenuhan kerja dalam persamaan regresi ganda dapat dijelaskan oleh kepercayaan diri dan reward bersamasama melalui persamaan regresi.

$\hat{\mathbf{Y}}=\mathbf{a}-\mathbf{b}_{1} \mathbf{X}_{1}-\mathbf{b}_{2} \mathbf{X}_{2}$

$\hat{Y}=8,639-0,620 X_{1}-0,269 X_{2}$

Interpretasi dari regresi di atas adalah sebagai berikut:

a. Konstanta (a) $=8,639$ artinya jika kepercayaan diri dan reward di obyek penelitian sama dengan nol (0), maka kejenuhan kerja (Y) sebesar 8,639. b. Koefisien regresi $\left(b_{1}\right)=0,620$ dan bertanda negatif, artinya jika variabel kepercayaan diri naik satu satuan, maka terjadi penurunan terhadap Y sebesar 0,620 (variabel kejenuhan kerja turun sebesar 0,620).

c. Koefisien regresi $\left(b_{2}\right)=0,269$ dan bertanda negatif, artinya jika variabel reward naik satu satuan, maka terjadi penurunan terhadap Y sebesar 0,269 (variabel kejenuhan kerja turun sebesar 0,269).

Pengujian signifikan dan linearitas persamaan regresi dapat dilihat pada Tabel 4.

Tabel 4 Nilai F hitung Kepercayaan Diri dan Reward terhadap Kejenuhan Kerja

ANOVA $^{b}$

\begin{tabular}{|ll|r|r|r|r|r|}
\hline \multicolumn{2}{|l|}{ Model } & \multicolumn{1}{|c|}{$\begin{array}{c}\text { Sum of } \\
\text { Squares }\end{array}$} & Df & Mean Square & F & Sig. \\
\hline 1 & Regression & 6420.688 & 2 & 3210.344 & 170.697 & $.000^{\mathrm{a}}$ \\
& Residual & 2407.327 & 128 & 18.807 & & \\
& Total & 8828.015 & 130 & & & \\
\hline
\end{tabular}

a. Predictors: (Constant), Reward, Kepercayaan_Diri

b. Dependent Variable: Kejenuhan_Kerja

Berdasarkan tabel 4, diperoleh $\mathrm{F}$ hitung sebesar 170,697 dengan signifikan 0,000 atau pada taraf $5 \%$ dengan df $\mathrm{n}-2$ $=129$ diperoleh $\mathrm{F}$ tabel $=3,087$. Maka $\mathrm{F}$ hitung $170,697>\mathrm{F}$ tabel 3,087, jadi Ho ditolak dan $\mathrm{Ha}$ diterima yang artinya kepercayaan diri dan reward secara bersama-sama berpengaruh negatif terhadap kejenuhan kerja guru honor
SD Negeri Se-Kecamatan Tualang Kabupaten Siak.

\section{b. Pengaruh Kepercayaan Diri $\left(\mathbf{X}_{1}\right)$ terhadap Kejenuhan Kerja (Y)}

Hipotesis kedua yang akan diuji adalah "Terdapat pengaruh negitf kepercayaan diri $\left(\mathrm{X}_{1}\right)$ terhadap kejenuhan kerja (Y)". pengujian 
hipotesis ini dengan menggunakan uji t dengan criteria.

c. Jika $\mathrm{t}$ hitung $>\mathrm{t}$ tabel maka Ho ditolak dan Ha diterima, artinya ada pengaruh signifikan kepercayaan diri terhadap kejenuhan kerja

d. Jika $t_{\text {hitung }}<t_{\text {tabel }}$ maka Ho diterima dan Ha ditolak, artinya tidak ada pengaruh signifikan kepercayaan diri terhadap kejenuhan kerja

Dari tabel 2 dapat dilihat nilai $\mathrm{t}$ hitung $=11,219$ dan $\mathrm{n}=131$, maka df $=\mathrm{n}$ $\mathrm{k},=131-2=129$. Dibandingkan dengan $t$ tabel pada $\mathrm{df}=131$ dengan taraf signifikan 5\%, maka di dapat nilai $t$ tabel $=1,960$. Kemudian dibandingkan antara $\mathrm{t}$ tabel dengan $\mathrm{t}$ hitung di dapat $\mathrm{t}$ hitung $(11,219)>t$ tabel $(1,960)$. Dengan demikian karena $\mathrm{t}_{\text {hitung }}>\mathrm{t}$ tabel maka Ho ditolak dan Ha diterima, artinya secara signifikan terdapat pengaruh kepercayaan diri terhadap kejenuhan kerja pada guru honor SD Negeri SeKecamatan Tualang Kabupaten Siak.

Dari hasil perhitungan standardize koefisien beta pada tabel 4.12, di dapat pengaruh kepercayaan diri terhadap kejenuhan kerja sebesar $0,697^{2}=0,485$. Artinya dalam penelitian ini kepercayaan diri mempengaruhi kejenuhan kerja sebesar $48,5 \%$.

\section{c. Pengaruh Reward $\left(\mathbf{X}_{2}\right)$ terhadap Kejenuhan Kerja (Y)}

Hipotesis ketiga yang akan diuji adalah "Terdapat pengaruh negitf reward $\left(\mathrm{X}_{2}\right)$ terhadap kejenuhan kerja (Y)". pengujian hipotesis ini dengan menggunakan uji $\mathrm{t}$ dengan kriteria.

a. Jika $\mathrm{t}_{\text {hitung }}>\mathrm{t}$ tabel maka Ho ditolak dan $\mathrm{Ha}$ diterima, artinya ada pengaruh signifikan reward terhadap kejenuhan kerja

b. Jika $t_{\text {hitung }}<t_{\text {tabel }}$ maka Ho diterima dan Ha ditolak, artinya tidak ada pengaruh signifikan reward terhadap kejenuhan kerja
Dari tabel 2, dapat dilihat nilai $\mathrm{t}$ hitung $=3,396$ dan $n=131$, maka $\mathrm{df}=\mathrm{n}$ $\mathrm{k},=131-2=129$. Dibandingkan dengan $\mathrm{t}$ tabel pada $\mathrm{df}=131$ dengan taraf signifikan 5\%, maka di dapat nilai $\mathrm{t}$ tabel $=1,960$. Kemudian dibandingkan antara $\mathrm{t}$ tabel dengan $\mathrm{t}$ hitung di dapat $\mathrm{t}$ hitung $(3,396)>t$ tabel $(1,960)$. Dengan demikian karena $\mathrm{t}$ hitung $>\mathrm{t}$ tabel maka Ho ditolak dan Ha diterima, artinya secara signifikan terdapat pengaruh reward terhadap kejenuhan kerja pada guru honor SD Negeri Se-Kecamatan Tualang Kabupaten Siak.

Dari hasil perhitungan standardize koefisien beta pada tabel 4.12, di dapat pengaruh kepercayaan diri terhadap kejenuhan kerja sebesar $0,211^{2}=0,045$. Artinya dalam penelitian ini reward mempengaruhi kejenuhan kerja sebesar $4,5 \%$.

\section{Keterbatasan Penelitian}

Meskipun peneliti sudah berusaha untuk mengurangi keterbatasan-keterbatasan dalam penelitian ini, namun masih ada keterbatasan-keterbatasan dalam penelitian. Keterbatasan-keterbatasan yang ada tidak mengurangi tingkat signifikan hasil penelitian, sehingga masih dapat dijadikan acuan dalam menurunkan kejenuhan kerja pada guru di sekolah. Keterbatasan-keterbatasan dalam penelitian ini antara lain: 1) Responden yang menjadi objek penelitian memiliki karakter yang berbeda-beda sehingga sulit untuk mendekati kenyataan yang sebenarnya sehingga memengaruhi analisis penelitian ini; 2) Dalam mengerjakan angket responden merasa tidak berkepentingan terhadap penelitian, sehingga responden kurang sungguhsungguh dalam mengisi angket; dan 3) Karena selain jumlah responden yang besar, juga responden tersebar di daerah pada radius yang berjauhan, maka 
timbul keterbatasan waktu, tenaga dan biaya.

\section{SIMPULAN, IMPLIKASI DAN SARAN}

\section{Simpulan}

Berdasarkan hasil pengujian hipotesis dan penelitian yang dilakukan, maka dapat diambil beberapa kesimpulan penelitian yang dirumuskan sebagai berikut:

1. Secara simultan terdapat pengaruh negatif kepercayaan diri $\left(\mathrm{X}_{1}\right)$ dan reward $\left(\mathrm{X}_{2}\right)$ terhadap kejenuhan kerja guru honor SD Negeri SeKecamatan Tualang Kabupaten Siak sebesar 72,7\% dalam kate gori kuat. Semakin tinggi kepercayaan diri dan reward yang didapatkan oleh guru honor maka akan semakin rendah kejenuhan kerja yang dialaminya. Sebaliknya semakin rendah kepercayaan diri dan reward yang didapatkan guru honor maka akan semakin tinggi kejenuhan kerja yang dialaminya.

2. Secara parsial terdapat pengaruh keyakinan diri $\left(\mathrm{X}_{1}\right)$ terhadap kejenuhan kerja guru honor SD Negeri Se-Kecamatan Tualang Kabupaten Siak sebesar 48,5\% dalam kategori cukup kaut. Semakin tinggi kepercayaan diri guru honor maka akan semakin rendah kejenuhan kerja yang dialaminya. Sebaliknya semakin rendah kepercayaan diri guru honor maka akan semakin tinggi kejenuhan kerja yang dialaminya.

3. Secara parsial terdapat pengaruh reward $\left(\mathrm{X}_{2}\right)$ terhadap kejenuhan kerja guru honor SD Negeri SeKecamatan Tualang Kabupaten Siak sebesar $4,5 \%$ dalam kategori sangat rendah. Semakin tinggi reward yang diperoleh guru honor maka akan semakin rendah kejenuhan kerja yang dialaminya.
Sebaliknya semakin rendah reward yang diperoleh guru honor maka akan semakin tinggi kejenuhan kerja yang dialaminya.

\section{Implikasi Penelitian}

Dalam penelitian ini sesuai hasil analisis dan kesimpulan penelitian pada dasarnya untuk memahami dan perumusan implikasi penelitian dalam hal ini terdapat pengaruh yang signifikan kepercayaan diri $\left(\mathrm{X}_{1}\right)$ dan reward $\left(\mathrm{X}_{2}\right)$ kesemuanya ini akhirnya dapat menurunkan kejenuhan kerja guru honor (Y), upaya dalam kaitannya untuk menurunkan kejenuhan kerja yaitu dengan cara meningkatkan kepercayaan diri dan reward.

Beberapa upaya yang harus dilakukan adalah Pertama, perlu adanya peningkatan kepercayaan diri guru honor agar terhindar dari berbagai dampak negatif seperti kejenuhan kerja. Kedua, bagi organisasi (sekolah maupun pihak terkait) agar memberikan penghargaan atau reward kepada setiap guru agar dapat meningkatkan kinerjanya dalam menjalankan tugas.

\section{Saran}

Berdasarkan hasil penelitian, kesimpulan dan implikasi penelitian yang telah ditemukan di atas, maka dapat disimpulkan beberapa saran berkaitan dengan kejenuhan kerja melalui kepercayaan diri dan reward. Saran-saran tersebut sebagai berikut:

1. Guru honor hendaknya selalu mengintrofeksi diri terhadap kemampuan yang dimiliki.

2. Guru honor sebaiknya meningkatkan kepercayaan diri agar terhindar dari dampak kejenuhan kerja

3. Pihak sekolah sebaiknya selalu memberikan kesempatan dan fasilitas kepada guru untuk mengembangkan potensi dirinya. 
4. Pihak sekolah sebaiknya selalu memberikan penghargaan atau reward bagi guru honor yang bertujuan untuk meningkatkan performa kerjanya

5. Pihak sekolah dan dinas terkait agar selalu memberikan sebuah penghargaan bagi guru-guru yang berprestasi dan memiliki potensi guna untuk membangkitkan semangat kerja dan memotivasi serta filosofi menjadi guru dengan terfokus pada alasan pribadi dan profesional agar guru dapat menyadari tujuan utama memilih profesi sebagai guru dan menikmati profesi yang dipilihnya

\section{DAFTAR PUSTAKA}

Cullen F. Bruece Barash G. Paul, Robert K. Stoelting, Michael K. Cahalan, M. Christine Stock dan Rafael Ortega., (2013), Clinical Anesthesia, Seventh Edition Lippincott Williams \& Wilkins

Dhian Zusmiasih Widiastuti dan Kamsih Astuti., (2010), Hubungan antara Kepribadian Hardiness dengan Burnout pada Guru Sekolah Dasar. Jurnal Psikolog, Fakultas Psikologi. Unibersitas Mercu Buana. Yogyakarta

Diah Restuning Maharani., (2011), Hubungan Antara Self Efficacy Dengan Burnout Pada Guru Sekolah Dasar Negeri X Di Kota Bogor, Jurnal Psikologi, Fakultas Psikologi, Universitas Gunadarma, Depok.
Direktorat PSMP., (2014), Buku Guru Pendidikan Pancasila dan Kewarganegaraan. Kementrian Pendidikan dan Kebudayaan. Jakarta

Gilbert Reyes, Joh D. Elhal, dan Julian D. Ford., (2008), The Encyclopedia of Psycological Trauma. John Weley \& Sons. Inc. New Jersey Canada.

Jarot Wijanarko., (2005), Mendidik Anak. Gramedia Pustaka Utama, Jakarta
Ramon Diaz., (2007), Hubungan Burnout dengan Motivasi Berprestasi Akademis pada Mahasiswa yang Bekerja. Skripsi. Fakultas Psikologi. Universitas Gunadarma. Depok.

Riduwan., (2005), Belajar Mudah Penelitian untuk Guru-Karyawan dan Peneliti Pemula. Bandung Alfabeta.

Sugiyono., (2010), Metode Penelitian Pendidikan, Alfabeta, Bandung

Ulfiani Rahman., (2007), Mengenal Burnout pada Guru. Lentera pendidikan, Edisi X, No. 2 hal 218

Wanabakti Anggih P. dan Nelman Dwihardo H., (2011). Pengaruh Pelatihan Penerapan SOP, Reward System, Lingkungan Kerja dan Peralatan terhadap Produktivitas Teknisi. Tugas Akhir. Jurusan Mesin. Fakultas Teknik. Universitas Hasanuddin. Makasar 